Vol. 8, Issue 10, October 2021

DOI: $10.17148 /$ IARJSET.2021.81024

\title{
Vegetation analysis of Harda district of Madhya Pradesh, India
}

\author{
Jeetendra Sainkhediya \\ Department of Botany, PMB Gujarati Science College Indore (M.P.)
}

\begin{abstract}
Harda district is situated in the eastern part of Madhya Pradesh, India. The southern part of the Harda district is covered by Satpura hill ranges and extended part of Malwa plateau with no obvious natural boundary that can held any endemic flora. Present study records 902 wild and naturalized species, 532 genera and 117 families in the $2645 \mathrm{sq} . \mathrm{km}$ where is 2.93 species density which show that the area is a meting ground for diverse floristic elements. 382 plant genera are monogeneric where each genus has only one species. Phytogeographical elements of Harda district have been analyzed which show that $33.11 \%$ species of this floristic element are native to India and adjoining areas.
\end{abstract}

Keywords: Harda, floristic elements, species density, Satpura hills, Malwa plateau.

\section{INTRODUCTION}

Harda district is one of the unexplored districts of Madhya Pradesh, India and it is situated in eastern part of Madhya Pradesh. It lies on $21{ }^{\circ} 53^{\prime}$ to $22^{\circ} 36^{\prime}$ longitude and $76^{\circ} 47^{\prime}$ to $77 \circ 20^{\prime}$ latitude. The area of the district is $2644.32 \mathrm{Sq}$. Km. of which forest covers $780.92 \mathrm{Sq}$. Km. Harda district is bounded by Sehore to the north, Hosangabad to the southeast, Khandwa to south and west and Dewas to northwest. The southern part of the district is covered by Satpura hill ranges and extended part of Malwa plateau. The soil of the area is black soil. The river, Narmada is the sole river of this area and tributaries are Ganjal, Anjal, Sukni, Midkul, Dendra, Machak, Syani and Kalimachak rivers. The rainfall of the area is $1124.2 \mathrm{~mm}$ the normal annual mean temperature is $32.8^{\circ} \mathrm{C}$ and minimum temperature is $19.8^{\circ} \mathrm{C}$. Thirty percent of its geographical area constitutes forest and covered by Satpura hill ranges, Malwa plateau and Narmada basin. It makes Harda district floristically very rich, unique and diverse. Before the present study, Harda was totally unexplored floristically.

Floristic diversity assessments are necessary to understand the present diversity status and conservation of biodiversity. Floristic study is a necessary prerequisite for much fundamental research in tropical community ecology. For the conservation and sustainable management of any forest; it requires a good knowledge of its biodiversity. [1] Hooker (1892-1897)) remarked that India has no native flora, as high amount of exotic floristic elements migrated in Indian flora. Recently brief account of vegetation and enumeration of species of some part of Harda region are given by few workers $[2,3,4]$.

\section{VEGETATION OF THE DISTRICT}

The forest in Harda district of Madhya Pradesh covers about 1,028 sq. km which is $30.87 \%$ of the total area [5].Topography, climate, soil types hilly ranges of Satpura, Narmada valley form great variation in vegetation resulting rich species diversity. As per the classification of the forests types by Champion and Seth (1968) [6] the forests of Harda district can be classified as follows:

\section{1) Tropical moist deciduous forests}

These types of forests are mainly deciduous species but sub dominants and lower story are covered by largely evergreen elements. These types of forest constitute the most diverse plant communities. It occurs in the southern hilliest portion of the district comprising Makrai, Sirali and Rahatgawoan. The evergreen habit of the lower story gives the forests as a whole a more or less evergreen appearance. Twiners and climbers are abundant in these forests. Most of the trees begin to shed their leaves in December, February. The forests look very much dry and blooming occurs in trees and shrubs during summer. The common tree species of these forests are Tectona grandis, Pterocarpus marsupium, Terminalia alata, Dalbergia paniculata, Bombax ceiba, Sterospermum chelonoides, Soymida febrifuga, Anogeissus latifolia, Mallotus philippensis, Diospyros melanoxylon, Buchanania cochinchinensis, Cassia fistula, Helicteres isora, Grewia tilifolia, Holarrhena pubescens, are common. These species constitute the top storey of the forests. The common climbers of these forests are Milletia extensa, Ventilago denticulata, Celastrus paniculatus, Dioscorea bulbifera, Dioscorea pentaphylla, Dioscorea oppositifolia. The undergrowth in dense forest is mostly sparse. This group of forests has been further divided on the basis of predominance of a particular species into (A) Boswellia forests (B) Butea forests (C) Khair forests. 


\section{International Advanced Research Journal in Science, Engineering and Technology}

Vol. 8, Issue 10, October 2021

\section{DOI: 10.17148/IARJSET.2021.81024}

(A) Boswellia forests: An open forests in which Boswellia forms a cover wood to stunted trees and shrubs of dry deciduous forests. It is confined on southern west parts of Satpura hill tracts. The dominant tree species are Tectona grandis and Terminalia elliptica sparse trees species are Acaccia nilotica, Anogeissus latifolia and Nyctanthes arbortristis, Lannea coromandelica, Albizia lebbek and Anogeissus latifolia.

(B) Butea forests: This type of forest mostly occurs in the northern part of the Harda district along the river Narmada. The common tree species of this region are Butea monosperma, Acacia lecophloea, Ziziphus jujuba, Z. xylopyrus, Helicteres isora, Grewia tiliifolia, Acaccia catechu, Casia fistula and Wrightia arborea.

(C) Khair forests: This type of forest occur in the under story in Tectona grandis and mixed forests. Found in the mixed forest of Sirali and Handia ranges along Machak River. The floristic composition in the Khair forests is as under :The top story consist Acacia catechu, Anogeissus latifolia, Diospros melanoxylon, Lagerstromia parviflora, Dalbergia sissoo. The middle story is made of Ziziphus xylopyrus, Flacourtia indica and Holarrhena pubescens. Among shrub and herbs the main are Lantana camara, Ziziphus nummularia, Senna tora, Indigofera cordifolia, Crotalaria prostrata and the common shrubby and herbaceous elements. The grass elements chiefly include Heteropogone contortus, Eragrostis tenella, Dicanthium pertusum, Cynodon dactylon and Eragrostella bifaria.

2) Tropical dry deciduous forests: The Tropical dry deciduous forests are confined to the Rhatgawoan, Sirali and Magardha. In these the dominants are almost entirely deciduous and lower storied trees and shrubs are also composed of several deciduous species. Tectona grandis (Teak) abundant in most of the deciduous forests and forms a dominant community. Along with other tree species are of Anogeissus latifolia, Pterocarpus marsupium, Soymida febrifuga, Diospyrous melonoxylon, Anogessus latifolia, Boswelia serrata, Hardwickia binata, Aegle marmelos, Madhuca longifolia, Dalbergia paniculata, Dalbergia latifolia, Terminalia bellirica, Terminalia cuneata, Albizia lebbeck, Haldina cordifolia and Bombax ceiba. Middle canopy is consist of smaller trees and shrubs like Acaccia chundra, Ziziphus nummularia, Gardinia resinifera,Grewia abutilifolia,Woodfordia fruiticosa, Diospyros chloroxylon, Wrightia arborea, Cassia fistula, Dolicandrone falcata, Lannea coromandelica, Spermadictylon suveolens, Nyctanthes arbortristis, Carissa opaca, Vitex negundo, and Catunaregam spinosa. The common climber species are Wattakaka volubilis, Tinospora cordifolia, Milletia extensa, Dioscorea pentaphylla, Ampelocissus latifolia, Canavalia gladiata, Cissampelos pareira, Capparis zeylanica, Cocculus hirsutus and Cryptolepis buchanania.

Ground cover of the forests is dominated by annual Herbs. Common plants of these category are Acanthospermum hispidum, Alysicarpus bupleurifolius, Senna tora, Corotalaria medicaginea, Indigofera cordifolia, Bidens biternatea, Rungia repans, Corchorus asters, Xanthium strominum, Ocimum americanum, Ocimum canum, Zornia gibbosa, Enecostema axillare, Sida cordifolia, Hibiscus abelmoschatus, Alternanthera bettzickiana, Alternanthera tenella, Crotalaria albida, Desmodium trifloram, Euphorbia hirta and Achyranthes aspera. The common grass are Arthaxon lanceolatus, Arundinella pumila, Alloteropsis cimicina, Andropogone pumilus, Apluda mutica, Dichanthium aristatum, Spodiopogone rhizophorus, Tripogone lisboae, Aristida adscensionis, Cynodon dactylon, Cenchrus ciliaris, Dactyloctenium aegypticum, Dichanthium pertusum, Themeda quadrivalvis and Seteria pumila.

\section{Scrub forests}

This is a transitional zone between open mixed forests and dry grasslands. The anthropogenic interference and excessive grazing pressure have caused sparse trees layer and discontinuous vegetation while shrubs and bushes become comparatively dense. The vegetation is characterized by shrubby and small thorny bushes. The dominant plant species confined in the scrub forest is Acacia leucophloea, Holoptelea integrifolia, Flacourtia indica, Butea monosperma, Maytenus senegalensis, Lannea coromandalica, Ziziphus oenoplia, Vitex negundo and Woodfordia fruticosa. The common twiners and climbers are Millettia extensa, Tinospora cordifolia, Wattakaka volubilis and Cissampelos peureira. The common grass species are Aristida fumiculata, Apluda mutica, Dichanthium kuntzeanum, Cenchrus ciliaris, Iseilema prostratum, Panicum paludosum, Seteria pumila and Themida quadrivalvis. The area is harbor rich glassland vegetation, rivers, big ponds. These plants can be grouped as follows.

\section{A. Grasslands}

Grasslands are found around Handia, Nandra, Allanpur, Ratatalai, Timarni and Harda. Dominant grasses are Apluda mutica, Aristida adscensionis, Brachiaria eruciformis, Cenchrus ciliaris, Cynodon dactylon, Dichanthium aristatum, Echinochloa colonum, Heteropogone contartus, Themeda laxa, Seteria pumila. Some other plants species of Crotalaria albida, Indigofera duthiei, Cassia tora, Tephrosia parpurea and number of other legumes are found growing in these grasslands. Other common species are Tribulus terrestris, Themeda quadrivalvis, Sehima nervosum, Chrysopogon fulvus, Iseilema laxum, Eleusine indica found in this grassland. Rice cultivation is common and Oryza rufipogon wild relative of rice is also common.

\section{B. Vegetation along rivers and stream banks:}

The rivers and streams which are flooded during monsoon are practically dry for major part of the year. Common trees along the banks of rivers and streams are Delbergia sissoo, Diospyros melanoxylon, Syzygium cumini, Vitex nergundo, Cretava magna, Holoptelea integrifolia, Mitragyna parvifolia. These tree species associates with few shrubs and 


\section{International Advanced Research Journal in Science, Engineering and Technology}

Vol. 8, Issue 10, October 2021

\section{DOI: $10.17148 /$ IARJSET.2021.81024}

twiners. These are Grewia tilifolia, Helicteres isora, Indigofera hirsuta, Vitex negundo, Woodfordia fruticosa, Rotula aquatic. Dry and sandy river beds harbour a large numbers of herbaceous species occurring along the river bank and cover ground layer. Common herbs are Alternanthera sessile, Bacopa monneiri, Eclipta alba, Stemodia viscosa.

\section{Pond vegetation:}

There are numerous ponds, rivers, tanks and ditches supporting aquatic plants to grow. Some of big pond in Harda beside Barnia and Son talai is the famous. Most of the ponds are filled up with water during monsoon in the second half of which a number of plants of the hydrophytic vegetation appear. The common aquatics plants are Eichhornia crassipes, Pistia stratiotes, Lemna minor, Spirodella polyrhiza, Hydrilla verticillata, Nymphaeae noucalli and Potamogeton crispus, while Ceratophylum demersum, Utricularia aurea, Ipomea aquatic, Trapa natans , Sagittaria parviflora, Rotala serphyllifolia, Hydrilla verticillata, Nymphaea nouchali, Polygonum plebeium, Rorippa indica, Stemodia viscose, Typha angustata, Valisneria spiralis, Ammannia baccifera, Alternanthera sessilis, Hygrophila schulli, Rumax dentatus, Scirpus roylei, Cyathocline purpurea, Eragrostis japonica, Eriocaulon cinereum, Fimbristylis bisumbellata, Ischaemum rugosum Poygonum glabum and Alternanthera philoxeroides, Sagittaria trifolia, Euphorbia caducifolia, Monochoria vaginalis.

\section{Flora of waste land}

Wastelands are uncared patches of land and it includes some localities like fallow land around field and roadside. The soil has plenty of calcium and magnesium salts. Chief floral elements of waste lands of Harda include Ageratum conyzoides, Alternanthera pungens, Amaranthus viridis, Argemone mexicana, Gnaphalium polycaulon, Canscora diffusa, Exacum pedunculatum, Calotropis procera,Cassia tora, Euphorbia hirta, Lucus biflora, Sida cordata, Rotala serpyllifolia, Solanum nigrum, Abutilon hirstum, Acalypha indica, Xanthium strumarium, Datura ferox, Ipomoea carnea, Verbascum chinensis and many grasses such as Seteria verticillata, Tripogone jacquemontii, Sporobplus fertilis, Pennisetum polystachyon, Andropogone pumilus, Cynodon dactylon .

\section{E. Hedge flora}

The boundaries of houses and gardens to screen out and keep away grazing and browsing animals, several trees and shrubs are grown as hedge plants. These plants species is given support to climbers and herbs. The common plants are Lawsonia inermis, Lantana camara, Pithecellobium dulce, Jatropha curcus, Accaia nilotica, Ziziphus mauritiana, Capparis separia, Capparis zeylanica, Clerodendrum inerme, Ipomea fistulosa, Opuntia elatior, Parkinsonia aculeate, Abrus precatorius, Cardiospermum halicacabum, Coccinia grandis, Pergularia damia, Teramnus labialis, Trichosanthes cucumerina, Bothriochloa pertusa, Lagascea mollis, Euphorbia thymifolia, Lantana camara, Caesalpinia bonduc, Jatropha curcus, Opuntia elatior, Leonotis nepetifolia etc.

\section{F. Epiphytic/ Parasitic plants}

Some of the common epiphytic plants of the Harda district are Acampe praemorsa, Vanda testacea and Vanda tessellata. Some of the epiphytic plants which also grow as lithophytic include Impatiens spp. and Tinospora cordifolia. Some of the common parasitic plants of the Harda district are Striga gesnerioides, Cuscuta chinensis, Cuscuta reffleca, Dendrophthea falcata, Viscum articulatum.

\section{G. Weed flora}

Weeds are unwanted plants which are invariably found in cultivated areas and constitute a sizable percentage of the vegetation. The main weeds are Alysicarpus pubescens, Alysicarpus rugosus, Amaranthus tricolor, Commelina forskalaei, Cyperous rotundus, Crotolaria juncea, Cyperus compressus, Dinebra retrofleaxa, Eclipta prostrate, Eleusine indica, Eclipta prostrate, Eragrostilla biflora, Eragrostilla brachyphylla, Eragrostilla atrovirens, Eragrostilla ciliaris, Euphorbia indica, Lucus cephalotus, Lagacea mollis, Hedyotis aspera, Physalis minima, Sonchus aspera, Vernonia cinerea, Ipomoea eriocarpa, Launaea procumbens, Portulaca oleracea,N Stemodia viscose, Themeda triandra, Ziziphus numularia, Portulaca quadrifida, Leucus aspera, Mililotus alba, Dinebra retroflexa, Digera muricata, Cichorium intybus, Chrozophora prostrate, Anagalis arvensis.

\section{H. Wall flora}

The deserted houses, old walls of temples, masjids and abandoned forts, shingled roofs of houses and even some newly constructed buildings support characteristic vegetation growing among the cracks and crevices. These are numerous old and dilapidated buildings and forts in the towns and villages of the region. Teli ki saray is one of them. Some noteworthy elements of the wall flora are Acalypha indica, Ageratum conyzoides, Aerva lanata, Boerhavia diffusa, Cyprus spp., Eragrostis minor, Euphorbia hirta, Achyranthus aspera, Amaranthus viridis, Chloris barbata Commelina benghalensis, Cynotis fasiculata, Chloris dolichostachya, Lindenbergia indica,, Evolvulus alsinoides, Tridax procumbens, Tripogone jacquemontii, Vernonia cinera, Setaria pumila, Nanorrhinum ramosissimum and Tribulus terrestris .

\section{METHODOLOGY}

Intensive floristic survey has been carried out in different seasons from 2011-2015 by well-planned schedule. For plant collection and preservation of voucher specimens standard methodology has been followed (Jain and Rao 1977) [7]. 


\section{International Advanced Research Journal in Science, Engineering and Technology}

Vol. 8, Issue 10, October 2021

\section{DOI: 10.17148/IARJSET.2021.81024}

Voucher specimens were collected in polybag and identified in the laboratory with the help of flora [8, 9, 10, 11, 12, $13,14,15]$. Recent up-to-date nomenclature of ICBN was followed. Herbarium specimens were deposited in PMB Gujarati Science College, Indore.

\section{RESULTS AND DISCUSSION}

Analysis of any flora depends upon the understanding of its geographical elements, which helps in correct interpretations of the flora. Present study records 902 wild and naturalized species of flowering plants which are distributed in 532 genera and 117 families. Dicotyledon represents 672 species, 397 genera and 95 families and monocotyledon represents 230 species, 135 genera and 22 families. The percentage of plant species in dicotyledons is $74.85 \%$ and the monocotyledons represent $25.4 \%$ but in the flora of world, the percentage of dicotyledons and monocotyledons are $81.3 \%$ and $18.7 \%$ respectively. Phytogeographical elements of Harda district have been analyzed showed that $33.11 \%$ species of this floristic element are native to India and adjoining areas. Poaceae (122) is the most dominant family in the study area. These Ten dominant families together contribute 521 species which account for $57.7 \%$ of the total flora while remaining 105 families with a total of 381 species representing $42.23 \%$ of the total flora. An analysis of life form shows that herbaceous plants (67\%) exhibit maximum diversity followed by trees (15), shrubs (11) and climbers (7\%). The relatively higher percentage of herbs may be due to predominant weed flora as well as low percentage of trees. 145 exotic plant species have been recorded in Harda district which are distributed in 42 families of angiosperms. These are naturalized in study area which accounts $16 \%$ of total flora.

\section{CONCLUSION}

The study documented the vegetation of the Harda district. This knowledge will be beneficial to explore plant utility in future. Phytogeographical elements of Harda district have been analyzed showed that $33.11 \%$ species of this floristic element are native to India and adjoining areas. The relatively higher percentage of herbs may be due to predominant weed flora as well as low percentage of trees. 145 exotic plant species have been recorded in Harda district it is showed that rich biodiversity of the area.

\section{ACKNOWLEDGEMENT}

Author feels honoured to extend grateful thanks to district administration of Harda, M. P. for providing facilities in Forest. Author is highly thankful to Dr. S. Ray for his guidance along with Dr. B. K. Shukla Senior Scientist, Botanical Survey of India, Allahabad and Dr. S. R. Yadav, Shivaji University, Kolhapur, Maharashtra, for their help in identifying some plant specimens.

\section{REFERENCES}

1. Hooker J.D. Flora of British India. Vol. 1-7. BSI Publication, Calcutta, India.1892-1897.

2. Sainkhediya and Ray. New addition to the flora of M.P. from Harda, India. Life Sc. Leaf. 61.pp. 37-41.2014.

3. Sainkhediya,J. Invasive alien flora of Harda district of Madhya Pradesh. IJAR.6:4.pp 343-346.2016

4. Sainkhediya,J. Ethnomedicinally importance vegetable family Cucurbitaceae in Harda district of M.P.India. Res. J. of multiple disciplines 1: 1.pp11-15.2015.

5. ISFR .India State of Forest Report .BSI,India.2011.

6. Champion and Seth.A Revised Survey of Forest Types of India , Manger of Pub. Delhi, India. 1968.

7. Jain and Rao A handbook of field and herbarium method, today and tomorrows. 1977.

8. Cook.Flora of the presidency of Bombay. Vol. 1-3. BSI Pub. Calcutta, India. 1903.

9. Gamble et alFlora of the presidency of Madras. Vol.1-3. BSI Publications, Calcutta, India.1915.

10. Haines,. The Botany of Bihar and Orissa.Vol.1-6.BSI Reprint, Calcutta, India. 1921-1924.

11. Duthie, Flora of the upper gangetic plains. Vol.2. BSI Publications Calcutta, India. 1960.

12. Verma D.M.; Balakrishnan N.P. and Dixit R.D. Flora of M.P.Vol.1 BSI Pub. Cal. India. 1994.

13. Mudgal V.; Khanna K.K. and Hajara P.K. Flora of Madhaya Pradesh, Vol. 2. BSI Pub. Cal.India. 1997.

14. Singh N.P.; Khanna K.K.; Mudgal V. and Dixit R.D. Flora of M. P.. Vol.3. BSI Pub. Cal.India. 2001.

15. Khanna K.K.; Kumar A.; Dixit R.D. and Singh N.P. Supplementary flora of M. P. BSI Pub., Cal.,India. 2001. 